\title{
Mapping in the Isukasia area
}

\section{J. H. Allaart, R. P. Hall, S. B. Jensen and O. Stecher}

During the summer of 1981 mapping of the two geological map sheets Ivisârtoq 64 V.2 N and Isukasia 65 V.2 S was begun, and mapping continued on the sheet Fiskefjord 64 V.1 N. The map areas are situated between $64^{\circ} 30^{\prime}$ and $65^{\circ} 30^{\prime} \mathrm{N}$ (fig. 15). A tent base camp was established at the fjord Kangiussaq in the eastern part of the Godthåb area. Thirteen geological field teams and the glaciological station at Qamanarssup sermia, $50 \mathrm{~km}$ to the south-east, were supplied from this base camp. A Jet Ranger helicopter from Heliswiss chartered through Greenlandair Charter and the GGU cutter J. F. Johnstrup provided transport to the teams. Field work will continue in the area in 1982.

J. H. A. mapped in an area $\left(50^{\circ} 00^{\prime}-50^{\circ} 30^{\prime} \mathrm{W}, 65^{\circ} 06^{\prime}-65^{\circ} 18^{\prime} \mathrm{N}\right)$ mainly consisting of gneiss along the north-eastern border of the Taserssuaq granodiorite body (Allaart et al., 1978) and north-west of the Amîtsoq gneiss block around Isukasia (fig. 15).

The eastern part consists of banded gneisses with some important occurrences of amphibolite. The main trend of structures and foliations is N-S.

The western part of the area consists of homogeneous, often veined gneiss. Darker and lighter types are closely intercalated in many places. Where age relations are discernible, the lighter gneiss is the youngest. The contact between the banded and the homogeneous gneisses trends practically $\mathrm{N}-\mathrm{S}$. The structures and foliations within the homogeneous gneisses trend however, NE-SW. In the northernmost part of the area the foliation within the homogeneous gneisses describes a NE-SW trending dome like structure. Basic intercalations are very common in the homogeneous gneisses, but they are always very discontinuous.

It has not been possible to determine the age relations between the Taserssuaq granodiorite and the gneisses.

There is an important set of $\mathrm{N}-\mathrm{S}$ trending faults in the area. The most important one has a mylonite zone of at least $100 \mathrm{~m}$ wide and is situated on the $50^{\circ} 10^{\prime} \mathrm{W}$ meridian. It is cut out in the south by the Ataneq fault (McGregor, 1979) that occurs at the north-west border of the Amîtsoq gneiss block in the south-eastern part of the map sheet.

S. B. J. mapped an area of homogeneous gneisses with layers and larger horizons of amphibolite west of the lake Taserssuaq in the south-western part of the map sheet area.

The homogeneous, grey biotite-gneisses are in amphibolite facies. Compositional banding is rarely developed, but the gneisses contain scattered amphibolite inclusions which are often more frequent near thicker amphibolite horizons.

The amphibolite horizons mapped generally show a monotonous character; foliated and more compact layers alternate. Ultramafic layers and lenses are often found within the amphibolite, but metasediments have not been observed. At one locality pillow lava structures have been preserved. The amphibolite horizons mapped show a complicated pattern, and dome and basin structures are often developed.

Throughout the area amphibolite horizons are cut by grey granitic bodies, which appear as concordant to subconcordant layers and lenses. Discordant pegmatite dykes and veins are associated with these granitic layers and agmatise the amphibolite layers. The granitic bodies predate the main structures in the area. 


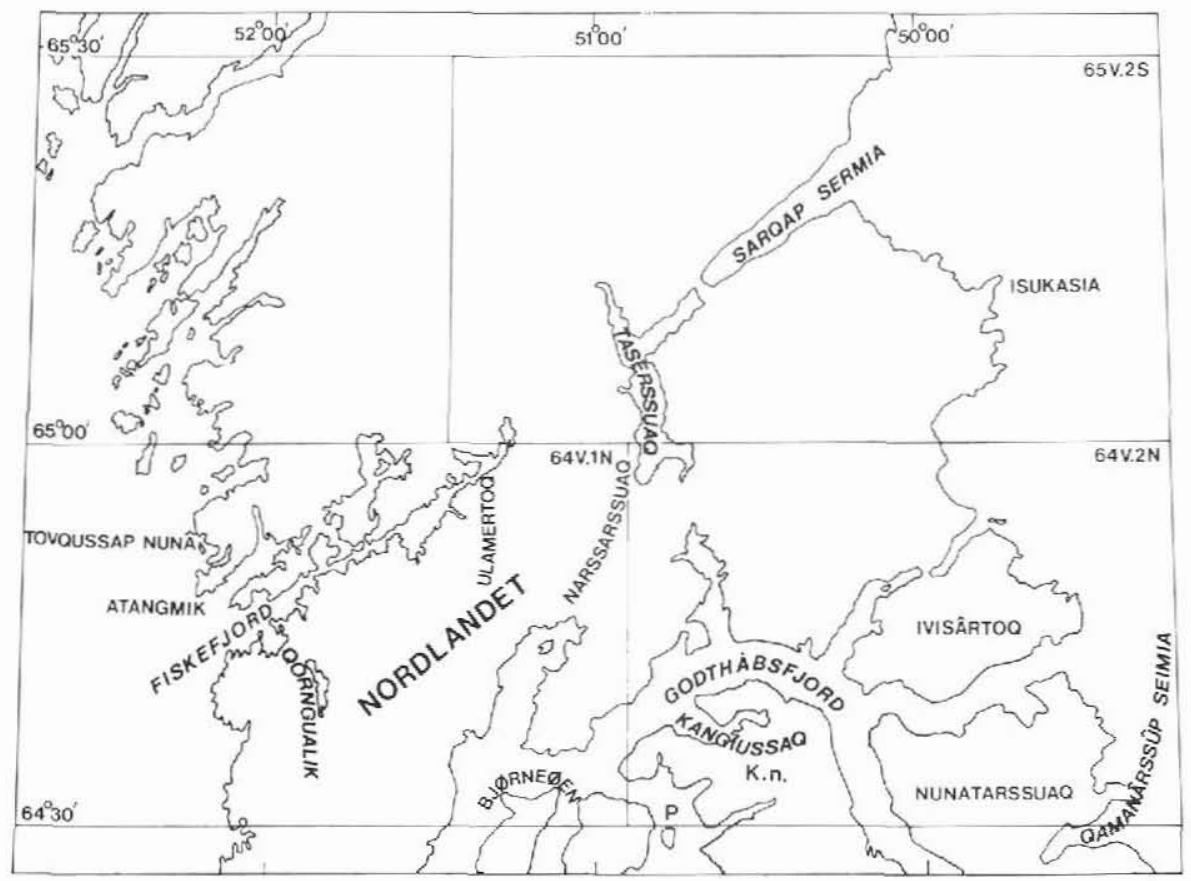

Fig. 15. Index map of the Godthảb region between $64^{\circ} 30^{\prime}$ and $65^{\circ} 30^{\prime}$. K. n. Kangiussap nunâ; P Pâtusôq.

R. P. H. and D. J. Hughes worked in the north-western quadrant of the map sheet and mapped units of amphibolite in which local pillow structures are developed, a suite of dioritic rocks, quartzo-feldspathic gneisses and the Taserssuaq granodiorite.

O. S. mapped to the north of the glacier Sarqap sermia in the north-western corner of the map sheet. He investigated a complex of gneisses and intricately folded amphibolite horizons and associated ultrabasic rocks, which appear to form a thrust sheet overlying the Taserssuaq granodiorite. The age of the gneisses and amphibolites is not known.

\section{References}

Allaart, J. H., Friend, C. R. L., Hall, R. P., Jensen, S. B. \& Roberts, I. W. N. 1978: Continued 1:500 000 reconnaissance mapping in the Precambrian of the Sukkertoppen region, southern West Greenland. Rapp. Gronlands geol. Unders. 90, 50-54.

McGregor, V. R. 1979: Archean gray gneisses and the origin of the continental crust: Evidence from the Godthåb region, West Greenland. In Barker, F. (edit.) Trondhjemites, dacites and related rocks. 169-204. Amsterdam: Elsevier.

R. P. H.

Department of Geology,

Portsmouth Polytechnic,

Burnaby Road.

Portsmouth POI $3 Q L$,

U.K.
O. S., Laboratoriel for Endogen Geologi, Geologisk Institut, University of Aarhus. Ole Worms Alle. 8000 Arhus C:

Denmark. 